\title{
Internet Use in Latin America
}

\author{
Ryan Salzman ${ }^{1}$
}

Alan B. Albarran ${ }^{2}$

\begin{abstract}
This paper explores the development of Internet use in Latin America. The analysis explores the macro- and microsocial expectations and actualities of Internet use in Latin America. While much is assumed about Internet penetration in the region, this paper lays out actual penetration rates, and attempts to understand what has fostered Internet growth in the region. Various levels of economic, technological, and governmental development encourage the expansion of Internet penetration in the region. By looking at micro-level Internet consumption, this research employs Latin American Public Opinion Project survey data taken from multiple years and offers an initial analysis of the determinants of Internet use. Compared to other forms of news media consumption, Internet users are younger and more skeptical of domestic news media.
\end{abstract}

Key words: Internet, Internet penetration, new media, media consumption, political economy of information.

\section{El uso de Internet en América Latina}

\section{Resumen}

Este documento analiza el desarrollo del uso de Internet en América Latina. Los análisis exploran las expectativas y realidades macro y micro sociales del uso de Internet en la región. Mientras se conjetura tanto acerca de la penetración de Internet en América Latina, este documento establece las tasas reales de penetración, e intenta comprender qué ha fomentado su crecimiento en la región. Diferentes niveles de desarrollo económico, tecnológico y gubernamental impulsan la expansión de la penetración de Internet en la región. Al observar el consumo en un nivel micro, esta investigación emplea datos de encuestas de varios años del Proyecto de Opinión Pública de América Latina (Latin American Public Opinion Project) y ofrece un análisis inicial de los factores determinantes del uso de Internet. En comparación con otras formas de consumo de medios de comunicación, los usuarios de Internet son más jóvenes y más escépticos a los medios de prensa locales.

Palabras clave: Internet, penetración de Internet, nuevos medios de comunicación, consumo de medios, economía política de la información.

Para citar este artículo To reference this article Para citar este artigo

Salzman, R., Albarran, A. B. Diciembre de 2011. Internet Use in Latin America. 14 (2), 297-313 


\section{O uso da Internet na América Latina}

\section{Resumo}

Este documento analisa o desenvolvimento do uso da internet na América Latina. As análises exploram as expectativas e realidades macro e microssociais do uso da internet na região. Enquanto se conjetura tanto sobre a inserção da internet na América Latina, este documento estabelece as taxas reais de sua inserção e tenta compreender o que tem fomentado o crescimento da internet na região. Diferentes níveis de desenvolvimento econômico, tecnológico e governamental impulsionam a expansão da inserção da internet na região. Ao observar o consumo da internet em um nível micro, esta pesquisa emprega dados de enquetes de vários anos do Projeto de Opinião Pública da América Latina (Latin American Public Opinion Project) e oferece uma análise inicial dos fatores determinantes do uso da internet. Em comparação com outras formas de consumo de meios de comunicação, os usuários de internet são mais jovens e mais cépticos aos meios de imprensa locais.

Palavras-chave: internet, inserção da internet, novos meios de comunicação, consumo de meios, economia, política da informação. 
Internet use exploded throughout the world during the last decade. Relative to use levels in the 1990s, each region experienced growth in Internet use. Accumulated knowledge of the patterns of Internet use in Latin America, however, remains minimal. While researchers make surmises and assumptions based on observations of other areas, little systematic analysis exists. This paper endeavors to offer a broad view of Internet use in Latin America over time, across countries, and among individuals.

Understanding Internet use in Latin America is important for many reasons. First and foremost, the rapid growth of Internet use in industrialized areas of the world signals a potential for Internet saturation in developing regions in the future. It is important to assess whether the patterns of saturation in Latin America are following the steep linear climb experienced in areas like the United States. If so, research looking at the effect of Internet use in developed regions may serve as a good starting point for research in the context of emerging markets. If they are not, a reconceptualization of the implications of Internet use may be required for studying emerging markets. Second, the Internet provides an important function as a news medium, just as television and newspapers do. Other research emphasizes the importance of understanding the influence of news media consumption as a key to understanding democracy in Latin America (Diamond, 2008, p. 99). If there are political effects or democratic payoffs when citizens have access to media and information (Lipset, 1960), then examining Internet use may hold the key to understanding the relationship between news media consumption and political attitudes and behavior in the future.

\section{Literature Review}

Research exploring Internet use in Latin America remains in its infancy relative to research on traditional news media. The expansion of Internet use in the region is well documented by journalists in traditional media and Internet media. Walsh (2010) describes the expansion of Internet capabilities and Internet use in Latin America. Numerous articles and posts describe a similar condition for Internet use in the region (Bonello, 2009; Leggatt, 2009; Seguic, 2011). However, a systematic study of what shapes Internet use in Latin America remains yet untouched.

Studies published from 1990 to 2005 recognized the Internet to be a "new" medium. While the Internet today still is considered a new medium, it is increasingly entrenched in various aspects of daily life for many Latin Americans. As Internet studies progressed, they mirrored the research done on other types of news media. That is, early reservations about the negative potential of the Internet in developing regions gave way to an embrace of the Internet as a source of democratic development in its ideal form (see Corrales, 2002 for both types of examples). However, while academic research focusing on the potential effects of Internet use expanded greatly (see Boas, 2008; Franda, 2002; Tolbert \& McNeal, 2003; Ward, Owen, Davis \& Taras, 2008), little work has focused strictly on understanding what affects Internet use first and foremost. Given this situation, this research focuses on a series of fundamental questions useful for expanding the general knowledge of what shapes Internet use in Latin America. Multiple research questions are addressed herein:

RQ1: What is the macro-social condition of Internet use in Latin America?

RQ2: Who uses the Internet in Latin America?

RQ3: How does Internet consumption compare to consumption of other news media?

As there is little systematic work to build on for shaping this research paper, a set of theoretical 
expectations is laid out prior to executing the data analysis. In general, a significant amount of research has emphasized the importance of understanding media conditions and behavior patterns for society at large (see Rockwell and Janus, 2003). Research on media and politics is replete with projects attempting to identify the actual effects of media conditions (see Salzman and Salzman, 2010) and individual-level media use (see Norris, 2000). While media effects are easily identified in controlled settings such as experiments (see Nelson, Clawson \& Oxley, 1997), the effects of media use are less clear in a broader societal context. This paper looks to add to that theoretical construct by considering what shapes Internet use, as those factors may be better predictors of eventual behavior than media use itself.

\section{Macro-level Expectations}

Media penetration variably can shape societal development (Nie \& Erbring, 2002). Therefore, it is useful to understand the development of Internet use in Latin America. Because Latin America is not unique in its adoption of the Internet as a viable source of information, entertainment, and commerce, Internet use is expected to have increased in all countries in Latin America over time, as it has elsewhere.

The factors that might condition that expected growth over time are less certain. While general economic growth may be seen as sufficient for Internet growth, there is reason to believe it is more complex. According to Hoffman (2004, p. 247), "the new information and communication technologies (i.e. Internet) neither spread around the globe in a uniform way, nor do they have universal political and developmental implications, nor is their diffusion a mere function of economic wealth." The author goes on to assert that Internet development issues are more social, economic, and political than technical. Internet development could be influenced by limitations placed on media of all kinds by governmental and societal actors. That is, Internet developers working in societies with greater limits on newspaper or television news production may proceed in a more cautious manner that leads to slower Internet development. Those limitations are conceived as press freedom. Countries with greater press freedom should have greater Internet penetration. Internet penetration is measured as the percentage of the entire population of a country that uses the Internet. Likewise, countries with greater economic, human, and communication development are expected to have greater Internet penetration.

\section{Micro-social Expectations - Internet Use}

This research identifies three types of factors that may impact Internet use for individuals in Latin America: ability, interest, and expectations. Those factors were employed by Salzman (2011) in analyzing the determinants of traditional news media consumption. An individual's ability to use the Internet can be contingent on the amount of wealth possessed by that individual. Individuals with greater wealth should be able to attain the proper hardware (i.e. a computer and some type of connection to the Web) in order to use the Internet. Also, because of higher density of communications infrastructure, individuals in more metropolitan areas should have greater access to Internet services that allow them to use the Internet. Finally, individuals living in countries with greater communication technology should be more likely to use the Internet.

Individuals' use of the Internet can be shaped by their interest in current events. Persons with greater political knowledge or formal education are likely to use the Internet more than those with less of each. Also, individuals who con- 
sume other news media should be more likely to use the Internet, because it is one more tool at their disposal. Latin Americans are expected to use the Internet more, because their interest in international affairs and economic conditions require knowledge of current events available via the Internet.

The third dimension that influences Internet use concerns the expectations individuals hold. The first expectation that is pertinent to influencing Internet use is the degree to which Latin Americans trust the news media in their country. Is Internet news an alternative to other news media or simply an extension of existing media? Given the multitude of Internet journalists and the relative lack of institutional controls on political actors, it seems Internet news is an alternative to traditional news and, thus, will attract individuals who may be turned off by traditional news media. Whereas trust in the news media may be expected to relate positively to consumption of the traditional news media, individuals with less trust in the traditional domestic news media are expected to consume more Internet news. Latin Americans who trust the news media will be less likely to seek alternative news sources only available on the Internet. Also, the level of press freedom in a country and the duration of democracy may influence Internet use. Where the press is more constrained, individuals should expect there is a greater chance the information they are consuming was manipulated. The same may be true of individuals living in countries that have less experience with democracy. In countries with limited democratic experience, ideas of free speech or a free press may not be as entrenched, making individuals more skeptical of the output of traditional news media. Those expectations may encourage Internet use, instead of traditional news media consumption. Latin Americans living in countries with lower levels of press freedom or shorter democratic duration may seek alternative news sources available via the Internet.

\section{Methodology}

The analysis employs a mixed methodology to understand Internet use in Latin America. First, aggregate data per country are analyzed, offering insights into the current state of Internet availability and use in Latin America. Next, the 2008 Latin American Public Opinion Project (LAPOP) is employed to explore average reported Internet use per country. The LAPOP data also are used to consider the individual-level determinants of reported Internet use among Latin Americans. ${ }^{3}$ Interviews are conducted door-todoor, using the next birthday system to promote the randomness of the sample. Samples are national in scope and do not focus solely on metropolitan areas. Oversampling is practiced where the population of a country has heterogeneous elements. This is done to ensure a balanced sample that is reflective of the actual population.

The aggregate data employed herein come primarily from the website Internet World Stats (2010). That web source utilizes different sources, including the United States Census Bureau, Nielson-Online, and the International Telecommunications Union (ITU), to compile information about Internet penetration and penetration growth per country in Latin America. Internet penetration is measured as the percentage of the population that is considered an Internet user. The growth statistics focus on the change in Internet users between 2000 and 2010.

\section{Assessing Internet Use in Latin America}

To answer the question of what influences aggregate levels of Internet penetration per coun-

3 LAPOP is hosted by Vanderbilt University and sustained through funds donated by the U.S. Agency for International Development (USAID), the Inter-American Development Bank (IDB), and the United Nations Development Programmed (UNDP). LAPOP data are collected and published every two years as the AmericasBarometer. Additional information can be found at their website http://www. vanderbilt.edu/lapop/index.php. 
try (RQ1), simple correlations between different development measures and Internet penetration are explored. Development can be economic, governmental, or social. Thus, measurements that capture each different type of development in the correlation models are included and detailed below.

GDP per capita measures the gross domestic product per capita in each country in 2005. GDP growth captures the growth rate of gross domestic product per country from 1990-2005. Government development conditions focus on the duration of democracy and the degree of press freedom. Democratic duration is taken from Smith (2005) and extended to 2008. Press freedom is derived from the Freedom House Freedom of the Press scores (Freedom House, 2008). The scores are inverted so that higher values equal greater press freedom. Human development is measured by the human development index, which considers health, knowledge, and standards of living (United Nations, 2008).

At the individual level, two basic measures of reported Internet use are employed. The first, Internet news, asks respondents "how often do you read the news on the Internet." Like the other news media consumption variables, Internet news is scaled from 0 to 3 , with 0 indicating "never" and 3 indicating "every day". Internet use captures general Internet use. It is rescaled at 1 to 5 , with 1 indicating "rarely" and 5 denoting "daily or almost daily". These variables will serve as dependent variables in the user models.

\section{User Model}

The Internet user models employ a three-dimensional framework that considers the influence of an individual's ability, interest, and expectations on their relative Internet consumption (RQ2). To test the role of the respondent's ability in influencing news media consump- tion, three variables are utilized: wealth, community size, and communication access. Exploring the role of interest in affecting the amount and type of Internet consumed by individuals, three variables are employed: political knowledge, education, and development. Also included as independent variables to test the interest dimension of news media consumption determinants are radio news, TV news, and newspapers. To test individual- and country-level conditions that may influence the expectations that drive various levels of news media consumption, three variables are included: trust in media, press freedom, and democratic duration.

Some basic control variables are added to ensure the correct relationships are identified and to increase the robustness of our models; namely, age and female. Refer to the Appendix for a detailed description of each variable.

\section{Results: Latin American Internet Use}

Table 1 illustrates the degree of Internet penetration per country in Latin America in 2010. There is substantial variation in Internet penetration across countries in Latin America. Nicaragua $(10.0 \%)$, Bolivia $(11.1 \%)$, and Honduras $(12.0 \%)$ have the lowest Internet penetration levels among the countries surveyed. Argentina $(64.4 \%)$, Uruguay $(52.8 \%)$, Chile $(50.0 \%)$, Colombia (48.7\%), and Costa Rica (44.3\%) have the highest degree of Internet penetration. The remaining countries have a wide distribution of Internet penetration. (Table 1).

While each country in Latin America increased its Internet penetration over the last decade, the degree of that increase is highly variable. Countries with the lowest Internet penetration growth rates had relatively high penetration already in 2000 . Chile (26.2\%), Uruguay (11.2\%), Peru (9.7\%) Argentina (6.9\%), and Costa Rica 
$(6.8 \%)$ had Internet penetration levels in 2000 that greatly exceeded the average of the remaining countries, which was somewhere between $0.5 \%$ and $2.0 \%$. Although some countries in Latin America were far ahead of others in Internet penetration in 2000, this did not necessarily dictate the amount of penetration ten years later. The Dominican Republic, for example, experienced an Internet penetration growth rate of $5,354 \%$ over the ten-year span from 2000 to 2010, ranking roughly near the average for the region and ahead of early Internet developer Peru. Likewise, countries such as Paraguay $(4,900 \%)$ and Guatemala (3,407\%) experienced tremendous growth rates, which - if continued - will help to close the penetration gap between the countries in the region. In general, countries with low Internet penetration in 2000 saw explosive growth over the next ten years. Correlations between Internet penetration rates per country in 2000 and 2008 came to 0.625 . For the years 2000 and 2010, the correlation was 0.597 . Positive correlation coefficients indicate that, when Internet use in 2000 is high, Internet use in 2008 or 2010 will be high as well. Thus, countries with high Internet penetration rates in 2000 maintained relatively high penetration rates over the next decade. Growth rates among countries with high initial penetration levels also were substantial, but inconsistent. Therefore, understanding early penetration data is only a part of understanding what shapes current levels of Internet use in Latin America.

To better comprehend what influences Internet penetration in the region, a series of analyses was conducted to uncover what conditions move in concert with Internet development in Latin America. The tests of relative economic development across Latin American countries, captured in the economic measure GDP per capita, reveal significant correlations with Internet penetration. A country's level of GDP per capita in 2005 is correlated highly in a positive direc- tion with its Internet penetration in $2008(\mathrm{r}=.849)$ and again in 2010 ( $\mathrm{r}=.890)$. Growth in GDP from 1990 to 2005 is correlated positively with Internet penetration and Internet penetration growth, but the relationship is weak, meaning they move in the same direction, but the magnitudes of change are dissimilar.

Government development also is thought to be a potential influence for expansion of Internet penetration. Correlations reveal Internet penetration in 2000 is related negatively to the length of democracy per country; however, by the late 2000s, that relationship had changed. Infrastructure development often occurred at a more rapid pace in countries that experienced autocratic leaders, such as Chile. This may help to explain how countries with a shorter democratic experience got ahead of other countries in Internet development. The shift in the relationship is such that democratic duration and Internet penetration are related positively, which may be an artifact of the region-wide expansion in Internet penetration and the pervasive positive relationship between democratic duration and economic development.

An additional measure of government development is captured in the degree of press freedom experienced in a country. Press freedom reflects the regular impediments placed on the press and can range from legal regulations to societal violence against journalists. The correlations reveal a consistently positive but weak correlation between press freedom and Internet penetration $(r=.200)$. Social development measured by the United Nations Human Development Index also is related positively to Internet penetration. Human development per country in 2008 is consistent in its positive relationship with the correlation for 2008 Internet penetration at 0.400 and at 0.504 for 2010. This relationship exceeds the government development measures, but falls short of the economic 
development measure based on GDP per capita. Therefore, the answer to RQ1 is that Internet penetration per country in Latin America in 2008-2010 is a function of Internet penetration in that country in 2000, the level of GDP per capita, the level of human development, and to a lesser extent - government development. Each development measure is related positively to Internet penetration, with the magnitude of that relationship varying considerably.

\section{Self-Reported Rates of Internet Use}

Shifting to an examination of the self-reported rates of Internet use per country, the 2008 Latin American Public Opinion Project reveals use trends are consistent with the penetration rates discussed above. However, it is important to recognize that the Internet use data employed herein are from the year 2008. The penetration rates discussed earlier are 2010 estimates. This change in time should have little effect, as penetration rates in 2008 and 2010 are correlated to the point of being collinear $(r=0.932)$. Although Internet use expanded between 2008 and 2010 in all the countries of Latin America, the major shifts in Internet penetration had occurred already.

A broad look at the LAPOP data reveals general trends in Internet use. A majority of Latin American respondents report rarely using the Internet (64\%). This is in line with what would be expected, given the low region-wide Internet penetration average of just over $30 \%$. The consistency of the two measures provides confidence for using the 2008 LAPOP data to examine the effects of Internet consumption.

Table 2 presents the average score for self-reported Internet use per country. While the scores are quite low, on average, the variation between the mean self-reported Internet use scores per country is quite significant. As expected, the country with the greatest Internet penetration, Argentina, also had the highest mean score for self-reported Internet use. Other high penetration countries like Brazil, Chile, Colombia, and Uruguay had corresponding self-reported Internet use rates that placed them near the top of all the countries in the region. Low penetration countries such as Nicaragua, Honduras, and Paraguay had low rates of self-reported Internet use. However, there are some apparent inconsistencies. Costa Rica, which has high penetration, had self-reported rates of Internet use that were relatively low. Peru, which has low to middle penetration, had high rates of self-reported Internet use. In general, the rates of self-reported Internet use per country match the relative Internet penetration per country. (Table 2).

Again, looking broadly at the LAPOP data can illustrate the regularity of Internet news consumption for Latin America. While fewer people use the Internet for news on a regular basis, the patterns closely mirror that of all Internet use in the region. Lower self-reported rates of news media consumption on the Internet are expected, because not everyone uses the Internet for the same reason. The similarity of the patterns of use lends confidence to the measure being accurate. Table 2 presents Internet use consumption rates per country. Again, Argentina leads other Latin American countries by a wide margin in Internet news consumption. Other countries with high penetration and general Internet use have correspondingly high Internet news consumption relative to other Latin American countries. Outside of Argentina, the average rates of reported Internet news consumption are only marginally different. Comparing Internet penetration statistics to the self-reported rates of Internet use in Latin America provides confidence that the data employed herein are reliable for ascertaining what influences Internet use. 


\section{Results: Individual-level Determinants of Internet Use}

Taking a closer look at what determines Internet use in Latin America (RQ2), a logistic regression analysis of the 2008 LAPOP data is employed. The analyses reflect what affects general Internet use and Internet news consumption. Coefficients in logistic analyses cannot be interpreted directly. For that reason, predicted probabilities have been included in the discussion of the results. Predicted probabilities illustrate the substantive change in the probability of choosing a specific survey response (i.e. "never" use the Internet), given a one unit or one standard deviation change in the independent variables of interest (i.e. wealth). Table 3 reveals the results of the ordered logistic regression, illustrating what factors determine Internet use in general and Internet news consumption specifically. Both measures are affected in nearly identical ways by similar factors. This was expected, because the aforementioned patterns of use for general Internet consumption and Internet news consumption were quite similar. The models performed well, explaining $26.3 \%$ of the variance in the all Internet use model and $19.8 \%$ of the variance in the Internet news model. (Table 3).

Like other news media, an individual's ability to access and spend time using the Internet and consuming Internet news is an important piece of the puzzle. Wealthier individuals and people living in larger communities consumed more Internet of all kinds. Not surprisingly, more Internet is consumed as you move from one community to another, larger community. That is, individuals in small cities consume more Internet of all kinds than individuals living in rural areas. Likewise, Latin Americans in large cities consume more Internet than those in small cities, and so on. As larger communities have greater access to the Internet, more Internet should be consumed. The same is true for greater access to Internet being available to individuals with more resources. Thus, the degree of access available to Latin Americans is important for understanding Internet use of all kinds.

Previous research has shown the ability-use relationship to be negative for radio news consumption, but positive for television and newspaper consumption (Salzman 2011). Internet use and Internet news consumption do not constitute an alternative source of information for Latin Americans with less wealth or those living in more rural areas, as does the radio. Living in countries with greater access to communication technology is related positively to Internet use. This is not surprising, because Internet use requires the most advanced technology of all media types.

Interest is also an important factor for understanding exactly who uses the Internet. Individuals with greater political knowledge use all types of media, including the Internet. Latin Americans' level of education also affects Internet use. However, the effect is stronger for those consuming all types of content versus strictly Internet news. Education only contributed to newspaper consumption in earlier analyses (see Salzmann, 2011). This indicates Internet use requires a skill set that is encouraged by formal education. Where newspaper consumers need only to be literate and have the wherewithal to purchase a paper, Internet users need basic computer skills beyond flipping a power button. It is also possible the better educated have employment that encourages/requires/facilitates Internet use.

In previous analyses of the other forms of newsmedia-consumption determinants, at least some substitutability of news media types was confirmed (see Salzman, 2011). Individuals who consume more than one kind of news media (e.g. TV) consume more of other types of news 
media (i.e. newspaper and radio). Substitutability is present for Internet use of all kinds, with one major exception. Television news consumption is unrelated to general Internet use or Internet news consumption. The reason for this exception is unclear, but perhaps the broad use of television undermines any potential statistically significant relationship.

The third set of factors expected to affect general Internet use and Internet news consumption concerns the type of expectations held by an individual as he/she relates to media. Neither living in a country with greater press freedom nor the duration of democracy in that country influences Internet use of any kind. Following the expectation that individuals with less trust in the media will use the Internet as an alternative information source, Latin Americans who are less trusting of the news media in their country consume more Internet news than their more trusting counterparts. However, the result of the predicted probability test reveals little substantive change when varying the level of trust in the domestic media. This indicates the Internet is used as an alternative news source for individuals seeking non-mainstream news. Radio is an alternative news source used by nontraditional news consumers. That is, radio news consumers are poorer and live in more rural areas (see Salzman 2011). The alternative nature of Internet news is captured in the attitudes, not the living conditions, of the individuals consuming it.

Although no explicit expectations were offered about the control variables age and gender, the findings are quite interesting. Like each other medium, compared to women, men consume more Internet. Counter to news media, younger individuals use the Internet more than older Latin Americans. Television news consumption and radio news consumption both are related positively to age. Newspaper consumption is related insignificantly to age. Thus, there is a substantial difference between who uses different media (RQ3).

The analyses of general Internet use and Internet news consumption reveal some useful insights. First, general Internet use and Internet news consumption are determined by similar factors. Second, an individual's ability to access the Internet is important and similar to television news and newspaper consumption. Third, Latin Americans who consume more/less television news do not necessarily mirror that use on the Internet. Fourth, Internet news is seen as an alternative source of news for consumers who are skeptical of domestic news sources. Finally, younger people consume more Internet than older Latin Americans.

\section{Conclusion}

Understanding Internet use in Latin America was the central focus of this paper. Employing a mixed method approach revealed strong findings about the state of Internet use in Latin America and the individual-level causes of Internet use. Here, some of the important findings are emphasized.

Internet use in Latin America has increased at a rapid rate since its introduction in the 1990s. A look at data describing Internet penetration shows there are many pieces to the puzzle of what shapes Internet penetration per country in the region. Economic development is correlated strongly with Internet penetration in 2010, and early Internet penetration rates also influenced later growth rates. Levels of human development and government development also positively impact Internet penetration in the region, but small correlation coefficients indicate those factors are less important in their impact. Understanding what shapes Internet penetration is important, since the Internet is the newest tool 
for communication. As communication shapes the relative attitudes and behavior of society, comprehending the patterns of communication expansion in emerging markets is paramount to appreciating the possible impact of that growth.

Self-reported rates of Internet use, provided by the 2008 Latin American Public Opinion Project, are in line with the macro-level Internet penetration rates analyzed, a fact that lends confidence to those self-reported measures. Also, self-reported Internet news consumption patterns reflect the patterns of general Internet use. This finding should allow future researchers to make certain assumptions about Internet news consumption, if only provided with general Internet news consumption measures.

The use models indicate resources and residency location shape Internet use in a substantial manner. Users' interest also plays a role, as Latin Americans with increased political knowledge consume more Internet content. Education is important, because the Internet requires some basic skills that must be learned. Interestingly, individuals who consume more/less television news do not practice similar habits on the Internet. Latin Americans who read the newspaper or listen to radio news, on the other hand, employ the Internet more. Expectations shaped by feelings about domestic media and democratic context lack an effect on Internet use, except in one major instance. Latin Americans who are less trusting of their domestic news media use the Internet for news gathering more than individuals who feel the news media are more trustworthy. Also, younger Latin Americans use the Internet more than their older counterparts. That finding confirms an important assumption held by Internet scholars in that there are systematic age differences for Internet users. The use model, therefore, paints a picture where Internet use requires abilities and some interest and trends towards younger Latin Americans.
However, Internet news also should be viewed as an alternative source of information for individuals who are skeptical of traditional news outlets.

The characteristics of Internet users can be useful for future research that attempts to identify the effects of Internet consumption on various types of behavior. For instance, recognizing that wealth and location are important for Internet use should assist political researchers as they shape their expectations about how Internet use affects political behavior. Wealthier individuals may exhibit systematic party preferences that also could be present for Internet users, given their propensity to be better off financially. Likewise, certain Latin American political parties may have a geographically specific political support base. In that case, parties that are popular in urban areas might do well to employ Internet advertising, which would appear to be relatively useless in rural settings. The findings of this paper should contribute to the theoretical constructs employed by political media researchers.

As this paper does not examine the impact on individual behavior, it is limited in its promotion of those ideas. That major limitation should be addressed in future research where Internet use is analyzed as a determinant of behavior. The results of this research should aid the theory building of that project substantially, as the characteristics of Internet users are now more clearly understood. Another limitation of this project is that so few Latin Americans use the Internet regularly. This research demonstrated that Internet penetration increases over time, which should hold true in the future. As more individuals use the Internet, the characteristics of an Internet user may shift. Only by reanalyzing similar data in the future will it be possible to see if these results are representative of general Internet use over time or if these outcomes merely represent Internet use in emerging markets. 


\section{References}

Boas, T. (2008). Chile: Promoting the personal connection. In S. Ward, D. Owen, R. Davis \& D. Taras (Eds.), Making a difference: A comparative view of the role of the Internet in election politics (pp. 15-34). New York: Lexington Books.

Bonello, D. (2009). Internet use grows in Latin America. Latimes.com. Retrieved June 20, 2011 from http://latimesblogs.latimes.com/laplaza/2009/01/ Internet-use-gr.html.

Corrales, J. (2002). Lessons from Latin America. In L. D. Simon, J. Corrales \& D. R. Wolfensberger (Eds.), Democracy and the Internet (pp. 30-66). Washington, D.C.: Woodrow Wilson Center Press.

Diamond, L. (2008). The spirit of democracy: The struggle to build free societies throughout the world. New York: Henry Holt and Company, L.L.C.

Franda, M. (2002). Launching into cyberspace: Internet development and politics in five world regions. London: Lynne Rienner Publishers.

Freedom House. (2008). Freedom of the press 2008: Press freedom rankings by region. Retrieved June 7, 2010 from http://www.freedomhouse.org/uploads/fop08/FOTP2008_RegionRankings.pdf.

Hoffman, B. (2004). The politics of the Internet in third world development: Challenges in contrasting regimes with case studies of Costa Rica and Cuba. New York: Routledge.

Internet World Stats. (2010). Latin American Internet usage statistics. Retrieved December 1, 2010 from www.Internetworldstats.com/stats10.htm.

Leggatt, H. (2009). Latin America is next Internet hotspot. BizReport. Retrieved June 20, 2011 from http://www.bizreport.com/2009/01/latin_ america_is_next_Internet_hotspot.html.
Lipset, S. M. (1960). Political man: The social basis of politics. Garden City, NY: Doubleday.

Nelson, T. E., R. A. Clawson \& Z. M. Oxley. (1997). Media framing of a civil liberties conflict and its effect on tolerance. American Political Science Review, 91(3), 567-583.

Nie, N. H. \& L. Erbring. (2002). Internet and society: A preliminary report. IT $\mathcal{E}$ Society, 1(1), 275-283.

Norris, P. (2000). A virtuous circle: Political communications in postindustrial societies. New York: Cambridge University Press.

Rockwell, R. J. \& N. Janus. (2003). Media power in Central America. Urbana, IL: University of Illinois Press.

Salzman, R. (2011). News media consumption in Latin America: Who does it? Journal of Spanish Language Media, 4(Feb.), 23-39.

Salzman, R. \& C. C. Salzman. (2010). Central American media: Testing the effects of social context. Journal of Spanish Language Media, 3(Feb.), 5-23

Seguic, J. (2011). Latin America's Internet population grows 15 percent in past year to 112 million people. comScore. Retrieved June 20, 2011 from http://www.comscore.com/layout/ set/popup/layout/set/popup/Press_Events/ Press_Releases/2011/3/Latin_America_s_Internet_Population_Grows_15_Percent_in_Past_ Year_to_112_Million_People.

Smith, P. H. (2005). Democracy in Latin America: Political change in comparative perspective. New York: Oxford University Press.

Tolbert, C. J. \& R. S. McNeal. (2003). Unraveling the effects of the Internet on political participation. Political Research Quarterly, 56(2), 175-185. 
United Nations. (2008). Human development reports: Frequently asked questions. Retrieved October 6, 2010 from http://hdr.undp.org/en/ statistics/faq/question,68,en.html.

Walsh, M. (2010). Nielson: Internet access on rise in Latin America. Online Media Daily. Retrieved
June 20, 2011 from http://www.mediapost. com/publications/?art_aid $=140861 \& f a=$ Articles . showArticle.

Ward, S., D. Owen, R. Davis \& D. Taras. (2008). Making a difference: A comparative view of the role of the Internet in election politics. New York: Lexington Books.

\section{Appendix}

\begin{tabular}{|c|c|}
\hline Variable & Description \\
\hline Internet News & $\begin{array}{l}\text { Single-item: Do you consume periodical news media and, if so, how of } \\
\text { ten? } 0=\text { never, } 1=\text { rarely, } 2=\text { once or twice weekly, } 3=\text { every day }\end{array}$ \\
\hline Internet Use & $\begin{array}{l}\text { Single-item: How often do you use the Internet? } 1=\text { rarely, } 2=\text { many } \\
\text { times annually, } 3=\text { at least once per month, } 4=\text { at least once per week, } 5 \\
=\text { daily or almost daily }\end{array}$ \\
\hline Wealth & $\begin{array}{l}\text { Index of dichotomous variables where } 1=\text { possess item, } 0=\text { do not pos- } \\
\text { sess item: Asked about television, refrigerator, land-line telephone, } \\
\text { cellular telephone, clothes washing machine, microwave oven, motor- } \\
\text { cycle, potable water in the house, computer and vehicle (the "vehicle" } \\
\text { question offered } 0-3 \text { ): Range }=0-13\end{array}$ \\
\hline Rural & $\begin{array}{l}\text { Dichotomous residence value assigned by LAPOP survey administrator } \\
1=\text { rural, } 0=\text { not rural }\end{array}$ \\
\hline Small City & $\begin{array}{l}\text { Dichotomous residence value assigned by LAPOP survey administra- } \\
\text { tor: } 1=\text { small city, } 0=\text { Not a small city }\end{array}$ \\
\hline Medium City & $\begin{array}{l}\text { Dichotomous residence value assigned by LAPOP survey administra- } \\
\text { tor: } 1=\text { medium city, } 0=\text { not a medium city }\end{array}$ \\
\hline Big City & $\begin{array}{l}\text { Dichotomous residence value assigned by LAPOP survey administra- } \\
\text { tor: } 1 \text { = big city, } 0=\text { not a big city }\end{array}$ \\
\hline Capital & $\begin{array}{l}\text { Dichotomous residence value assigned by LAPOP survey administra- } \\
\text { tor: } 1=\text { capital city, } 0=\text { not a capital city }\end{array}$ \\
\hline
\end{tabular}




\begin{tabular}{|c|c|}
\hline Variable & Description \\
\hline Communication Access & $\begin{array}{l}\text { Taken from the access sub-index of the International Communication } \\
\text { Technology Development Index. The access sub-index is a composite } \\
\text { measure of fixed telephone lines, mobile telephone subscriptions, inter- } \\
\text { national Internet bandwidth per Internet user, the proportion of house- } \\
\text { holds with a computer, and the proportion of households with Internet } \\
\text { access. Values are assigned per country. Higher scores indicate greater } \\
\text { access per country. Range } 2.54 \text { to } 5.27 \text {. }\end{array}$ \\
\hline Political Knowledge & $\begin{array}{l}\text { Indexed into summed dichotomous variables where } 1 \text { = correct answer, } \\
0=\text { incorrect answer: Asked to name the president of the United Sta- } \\
\text { tes, the head of the country's legislature, the number of provinces in the } \\
\text { country, the length of the presidential term, and the name of the Brazi- } \\
\text { lian president. Range } 0-5 \text {. }\end{array}$ \\
\hline Education & Continuous value in years of schooling completed, $0-18$ \\
\hline Development & $\begin{array}{l}\text { Taken from the United Nations Human Development Index. Re-scaled } \\
\text { at } 0-100 \text { with low scored indicating low development and high scored } \\
\text { indicating high development. }\end{array}$ \\
\hline TV News & $\begin{array}{l}\text { Single-item: Do you consume TV news media and, if so, how often? } 0= \\
\text { never, } 1=\text { rarely, } 2=\text { once or twice weekly, } 3=\text { every day }\end{array}$ \\
\hline Newspaper & $\begin{array}{l}\text { Single-item: Do you consume periodical news media and, if so, how of } \\
\text { ten? } 0=\text { never, } 1=\text { rarely, } 2=\text { once or twice weekly, } 3=\text { every day }\end{array}$ \\
\hline Radio News & $\begin{array}{l}\text { Single-item: Do you consume radio news media and, if so, how often? } 0 \\
=\text { never, } 1=\text { rarely, } 2=\text { once or twice weekly, } 3=\text { every day }\end{array}$ \\
\hline Trust in Media & $\begin{array}{l}\text { A single-item measure of people's reported confidence in the media: Re- } \\
\text { coded at } 1-7 \text { where } 1=\text { lowest confidence, } 7=\text { high confidence }\end{array}$ \\
\hline Press Freedom & $\begin{array}{l}\text { Taken from Freedom House's } 2008 \text { Press Freedom Index. Inverted scale } \\
\text { where } 0=\text { no freedom and } 100=\text { completely free (per country) }\end{array}$ \\
\hline Democratic Duration & $\begin{array}{l}\text { A count measure of the number of years of continuous democracy per } \\
\text { country taken from Smith (2005). Range } 10 \text { - } 57 \text { years. }\end{array}$ \\
\hline Age & Single-item: $16-97$ \\
\hline Female & Male $=0$, Female $=1$ \\
\hline
\end{tabular}


Table 1: Internet Use in Latin America

\begin{tabular}{|c|c|c|c|c|c|c|}
\hline COUNTRIES & $\begin{array}{c}\text { Population } \\
\text { (Est. 2010) }\end{array}$ & $\begin{array}{l}\text { Internet } \\
\text { Users }\end{array}$ & $\begin{array}{c}\text { Internet } \\
\text { Penetration } \\
2010\end{array}$ & $\begin{array}{c}\text { Internet } \\
\text { Penetration } \\
2000\end{array}$ & $\begin{array}{c}\text { User Growth } \\
(2000-2010)\end{array}$ & $\begin{array}{l}\% \text { Users } \\
\text { in Table }\end{array}$ \\
\hline Argentina & $41,343,201$ & $26,614,813$ & $64.4 \%$ & $20.0 \%$ & $964.6 \%$ & $13.3 \%$ \\
\hline Bolivia & $9,947,418$ & $1,102,500$ & $11.1 \%$ & $1.4 \%$ & $818.8 \%$ & $0.6 \%$ \\
\hline Brazil & $201,103,330$ & $75,943,600$ & $37.8 \%$ & $2.9 \%$ & $1,418.9 \%$ & $37.9 \%$ \\
\hline Chile & $16,746,491$ & $8,369,036$ & $50.0 \%$ & $26.2 \%$ & $376.2 \%$ & $4.2 \%$ \\
\hline Colombia & $44,205,293$ & $21,529,415$ & $48.7 \%$ & $2.1 \%$ & $2,352.1 \%$ & $10.8 \%$ \\
\hline Costa Rica & $4,516,220$ & $2,000,000$ & $44.3 \%$ & $6.8 \%$ & $700.0 \%$ & $1.0 \%$ \\
\hline Dominican Rep. & $9,823,821$ & $3,000,000$ & $30.5 \%$ & $0.7 \%$ & $5,354.5 \%$ & $1.5 \%$ \\
\hline Ecuador & $14,790,608$ & $2,359,710$ & $16.0 \%$ & $1.5 \%$ & $1,211.0 \%$ & $1.2 \%$ \\
\hline El Salvador & $6,052,064$ & 975,000 & $16.1 \%$ & $0.6 \%$ & $2,337.5 \%$ & $0.5 \%$ \\
\hline Guatemala & $13,550,440$ & $2,280,000$ & $16.8 \%$ & $0.6 \%$ & $3,407.7 \%$ & $1.1 \%$ \\
\hline Honduras & $7,989,415$ & 958,500 & $12.0 \%$ & $0.7 \%$ & $2,296.3 \%$ & $0.5 \%$ \\
\hline Mexico & $112,468,855$ & $30,600,000$ & $27.2 \%$ & $2.7 \%$ & $1,028.2 \%$ & $15.3 \%$ \\
\hline Nicaragua & $5,995,928$ & 600,000 & $10.0 \%$ & $1.1 \%$ & $1,100.0 \%$ & $0.3 \%$ \\
\hline Panama & $3,410,676$ & 959,900 & $28.1 \%$ & $1.6 \%$ & $2,033.1 \%$ & $0.5 \%$ \\
\hline Paraguay & $6,375,830$ & $1,000,000$ & $15.7 \%$ & $0.4 \%$ & $4,900.0 \%$ & $0.5 \%$ \\
\hline Peru & $29,907,003$ & $8,084,900$ & $27.0 \%$ & $9.7 \%$ & $223.4 \%$ & $4.0 \%$ \\
\hline Uruguay & $3,510,386$ & $1,855,000$ & $52.8 \%$ & $11.2 \%$ & $401.4 \%$ & $0.9 \%$ \\
\hline Venezuela & $27,223,228$ & $9,306,916$ & $34.2 \%$ & $4.1 \%$ & $879.7 \%$ & $4.7 \%$ \\
\hline TOTAL & $574,416,368$ & $200,144,290$ & $34.8 \%$ & & $1,024.9 \%$ & $100.0 \%$ \\
\hline
\end{tabular}

Source: World Statistics (retrieved January 10, 2011 from www.internetworldstats.com/stats10.htm) 
Table 2: Average Self-reported Internet Use Scores per Country in Latin America

\begin{tabular}{|c|c|c|}
\hline Country & $\begin{array}{l}\text { All Internet Use } \\
\text { (scaled 1-5) }\end{array}$ & $\begin{array}{l}\text { Read News on the Internet } \\
\text { (scaled } 0-3 \text { ) }\end{array}$ \\
\hline Argentina & $\begin{array}{c}3.02 \\
(1.73)\end{array}$ & $\begin{array}{c}0.92 \\
(1.13)\end{array}$ \\
\hline Bolivia & $\begin{array}{c}1.92 \\
(1.35)\end{array}$ & $\begin{array}{c}0.32 \\
(0.67)\end{array}$ \\
\hline Brazil & $\begin{array}{c}2.05 \\
(1.56)\end{array}$ & $\begin{array}{c}0.59 \\
(1.03)\end{array}$ \\
\hline Chile & $\begin{array}{c}2.15 \\
(1.60)\end{array}$ & $\begin{array}{c}0.58 \\
(0.99)\end{array}$ \\
\hline Colombia & $\begin{array}{l}2.02 \\
(1.45)\end{array}$ & $\begin{array}{c}0.36 \\
(0.78)\end{array}$ \\
\hline Costa Rica & $\begin{array}{c}1.77 \\
(1.30)\end{array}$ & $\begin{array}{c}0.24 \\
(0.69)\end{array}$ \\
\hline Dominican Rep. & $\begin{array}{l}1.62 \\
(1.26)\end{array}$ & $\begin{array}{c}0.26 \\
(0.70)\end{array}$ \\
\hline Ecuador & $\begin{array}{l}1.74 \\
(1.22)\end{array}$ & $\begin{array}{c}0.28 \\
(0.66)\end{array}$ \\
\hline El Salvador & $\begin{array}{l}1.80 \\
(1.39)\end{array}$ & $\begin{array}{c}0.27 \\
(0.70)\end{array}$ \\
\hline Guatemala & $\begin{array}{l}1.52 \\
(1.13)\end{array}$ & $\begin{array}{c}0.20 \\
(0.57)\end{array}$ \\
\hline Honduras & $\begin{array}{c}1.49 \\
(0.91)\end{array}$ & $\begin{array}{c}0.22 \\
(0.60)\end{array}$ \\
\hline Mexico & $\begin{array}{l}1.77 \\
(1.34)\end{array}$ & $\begin{array}{c}0.27 \\
(0.68)\end{array}$ \\
\hline Nicaragua & $\begin{array}{l}1.60 \\
(1.19)\end{array}$ & $\begin{array}{c}0.15 \\
(0.52)\end{array}$ \\
\hline Panama & $\begin{array}{l}1.84 \\
(1.33)\end{array}$ & $\begin{array}{l}0.27 \\
(0.67)\end{array}$ \\
\hline Paraguay & $\begin{array}{l}1.46 \\
(1.07)\end{array}$ & $\begin{array}{c}0.16 \\
(0.55)\end{array}$ \\
\hline Peru & $\begin{array}{c}2.34 \\
(1.56)\end{array}$ & $\begin{array}{c}0.44 \\
(0.80)\end{array}$ \\
\hline Uruguay & $\begin{array}{l}2.05 \\
(1.56)\end{array}$ & $\begin{array}{l}0.45 \\
(0.91)\end{array}$ \\
\hline Venezuela & $\begin{array}{c}2.05 \\
(1.42)\end{array}$ & $\begin{array}{c}0.39 \\
(0.79)\end{array}$ \\
\hline All Latin America & $\begin{array}{c}1.90 \\
(1.41)\end{array}$ & $\begin{array}{c}0.35 \\
(0.78)\end{array}$ \\
\hline
\end{tabular}

Standard deviation in parenthesis

Source: AmericasBarometer by Latin American Public Opinion Project 2008 
Table 3: Ordered Logistic Models of Internet Consumption Determinants

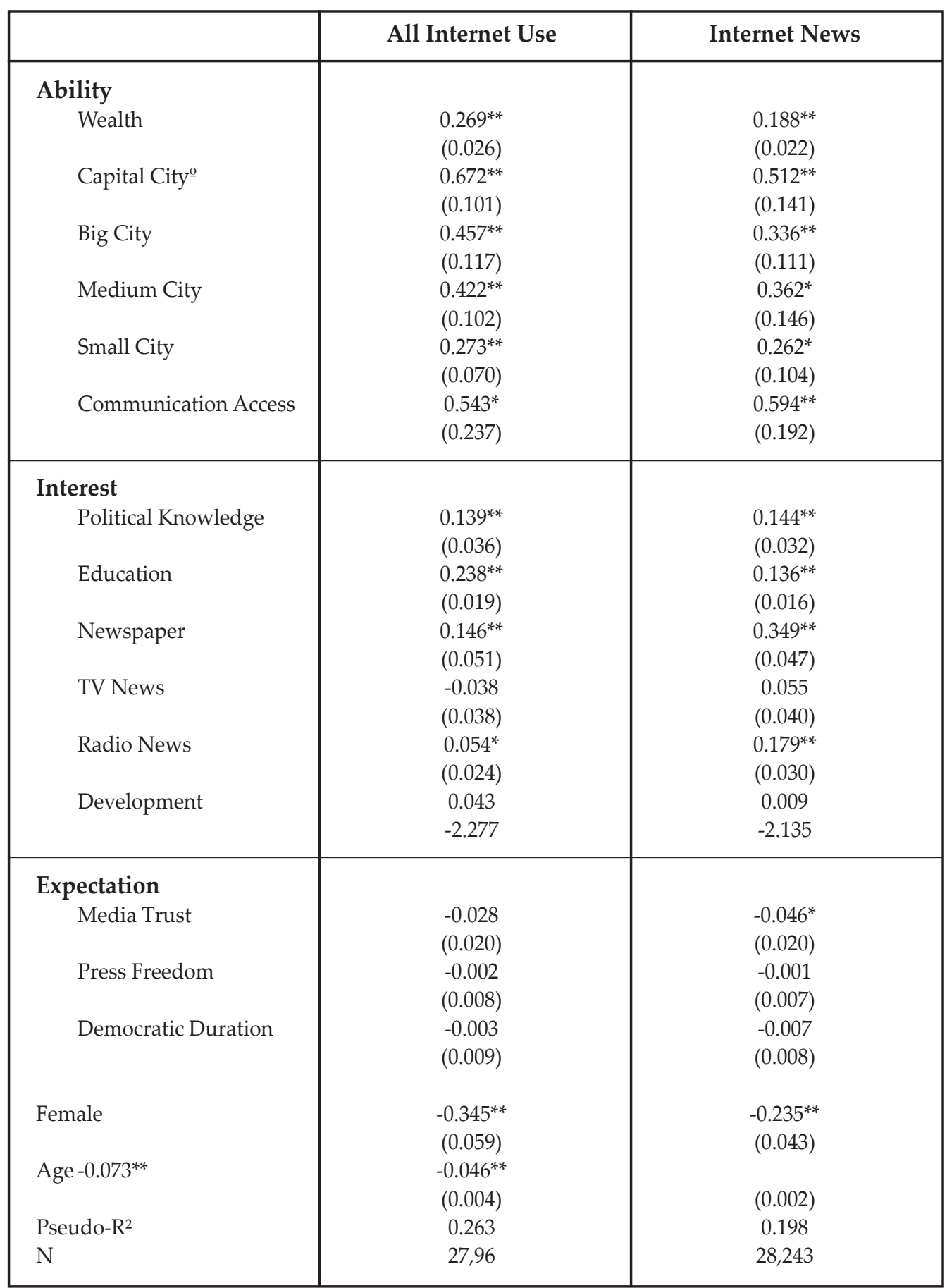

o Press Freedom, Development and Communication Access are identified per country ${ }^{*} \mathrm{p}<.05 ;{ }^{* *} \mathrm{p}<.01$ (two-tailed)

o The excluded category (for comparison) is Rural

Numbers in parenthesis indicate standard errors 